\title{
Utilization of Spent Coffee Grounds for Compost Production
}

\author{
Saritha B, Maria Subashini L, Aswathy.M
}

\begin{abstract}
Espresso is one of the most basic agrarian things on earth. The three principle trademark highlights of espresso are sharpness, smell and taste. Precisely when espresso is evacuated in water, the vast majority of the hydrophobic mixes, including oils, lipids, triglycerides, and unsaturated fats stay in the grounds, as do insoluble starches like cellulose and unmistakable unpalatable sugars. Setting up the soil with espresso waste is an incomprehensible strategy to utilize something that would by one way or another wind up expending room in a landfill. Treating the soil espresso beans adds nitrogen to the fecal matter store. The Main focal point of the examination is to use the accomplished espresso powder with soil to make it continuously rich and to consider the test system of experienced espresso powder with different side effects like, saw dust, wood chips, soil, and so forth. The different parameters, for example, $\mathrm{pH}$, temperature, Moisture content, $C / N$ degree, Phosphate, Sodium and Pottasium. apparently studied manure

Key words: Composting, Spent Coffee, $\mathrm{CN}$ ratio, $\mathrm{pH}$ and Saw dust
\end{abstract}

Espresso Coffee Coffee is one of the most fundamental regular things on earth. The three fundamental trademark features of coffee are causticity, smell and taste. It is gotten from in excess of 1500 creation substances, 850 unstable and 700 dissolvable. Right when coffee is disengaged in water a monster segment of the hydrophobic blends including oils, lipids triglycerides and unsaturated fats remain in the grounds as do insoluble starches like cellulose and specific dangerous sugars Collaborator lignin, cautious phenolics and the brilliant fragrance passing on essential oils are also present in coffee.

Noteworthy Varieties are Arabica - delicate coffee with more smell and gets higher market worth showed up contrastingly in association with Robusta beans. - Robusta has increasingly significant quality in the cup and used in making specific blends. - Arabica is made in higher climbs than Robusta. Coffee is one of the most eaten up refreshments on earth. A normal 3.5 billion cups of coffee are eaten up worldwide constantly. It is made in excess of 70 countries and totals to in excess of 16 billion pounds of

Revised Manuscript Received on July 22, 2019.

Saritha B, Associate Professor, Department of Civil Engineering Bharath University, Chennai, Tamil Nadu Email: sarichaks@gmail.com

Maria Subashini L, Assistant Professor, Department of Civil Engineering Bharath University, Chennai, Tamil Nadu mariasubashini80@gmail.com

Aswathy.M, Assistant Professor,, Department of Civil Engineering Bharath University, Chennai, Tamil Nadu email:aswathym026@gmail.com
Table 1 Total production of coffee by all exporting countries in thousand $60 \mathrm{~kg}$ bags in 2017 [3]

\begin{tabular}{|l|l|}
\hline Total & 151623 \\
\hline Arabicas. & 95204 \\
\hline Colombian Afilds. & 15779 \\
\hline Other Afilds. & 26951 \\
\hline Brazilian Naturals & 52474 \\
\hline Rebustas, & 56419 \\
\hline Africa & 16353 \\
\hline Asia \& Oceania & 43110 \\
\hline Mexico \& Central America & 17740 \\
\hline South America & 7420 \\
\hline
\end{tabular}

\section{EXPERIMENTAL STUDY}

\begin{tabular}{|l|l|l|l|l|l|}
\hline $\begin{array}{l}\text { Coffee } \\
(g)\end{array}$ & 100 & 100 & 100 & 100 & 100 \\
\hline $\begin{array}{l}\text { Saw } \\
\text { Dust } \\
\text { (g) }\end{array}$ & 100 & 200 & 300 & 400 & 500 \\
\hline
\end{tabular}

\begin{tabular}{|l|l|l|l|l|l|}
\hline $\begin{array}{l}\text { Coffee } \\
(\mathrm{g})\end{array}$ & 100 & 100 & 100 & 100 & 100 \\
\hline $\begin{array}{l}\text { Saw } \\
\text { Dust } \\
\text { (g) }\end{array}$ & 100 & 200 & 300 & 400 & 500 \\
\hline
\end{tabular}

With $100 \mathrm{ml}$ Cow Dung (Constant)

Table 3 Set 2 of the Compost

\begin{tabular}{|l|l|l|l|l|l|}
\hline $\begin{array}{l}\text { Coffee } \\
(\mathrm{g})\end{array}$ & 100 & 100 & 100 & 100 & 100 \\
\hline $\begin{array}{l}\text { Vegetable } \\
\text { waste }\end{array}$ & 100 & 200 & 300 & 400 & 500 \\
\hline
\end{tabular}


Table 4 Set 3 of the Compost

\begin{tabular}{|l|c|c|c|c|c|}
\hline $\begin{array}{l}\text { Coffee } \\
\text { (g) }\end{array}$ & 100 & 100 & 100 & 100 & 100 \\
\hline Soil & 100 & 200 & 300 & 400 & 500 \\
\hline
\end{tabular}

\section{METHODOLOGY}

\section{A. Procedural Work}

1) The inoculums brought from a functioning Cow Dung $100 \mathrm{ml}$

2) Substrate (Food) - Coffee squander, Saw dust, Vegetable Waste

3) Parameters - pH, Moisture content, Temperature, C/N proportion

4) Every day Monitoring

5) No of days - 30

6) Bin size width $12 \mathrm{~cm}$, stature $30 \mathrm{~cm}$ (12 Nos)

Scene Environmental Engineering Lab as in figure 4

The attributes of the waste are outlined in the Table

Table 5 Characteristics of Waste

\begin{tabular}{|l|l|l|l|l|}
\hline $\begin{array}{l}\text { CHARACT } \\
\text { ERISTICS }\end{array}$ & $\begin{array}{l}\text { METH } \\
\text { OD }\end{array}$ & $\begin{array}{l}\text { SAW } \\
\text { DUS } \\
\text { T }\end{array}$ & $\begin{array}{l}\text { CO } \\
\text { W } \\
\text { GUN } \\
\text { G }\end{array}$ & $\begin{array}{l}\text { COFFE } \\
\text { E } \\
\text { WASTE }\end{array}$ \\
\hline pH & $\begin{array}{l}\text { pH } \\
\text { Meter }\end{array}$ & 4.7 & 7.8 & 8.0 \\
\hline $\begin{array}{l}\text { Temperature } \\
\text { C }\end{array}$ & $\begin{array}{l}\text { Stem } \\
\text { Thermo } \\
\text { meter }\end{array}$ & 27 & 24 & 24 \\
\hline $\begin{array}{l}\text { Moisture } \\
\text { Content }\end{array}$ & $\begin{array}{l}\text { Hydrom } \\
\text { eter }\end{array}$ & 40 & 65 & 65 \\
\hline Carbon (\%) & IS 2720 & 42 & 42 & 67 \\
\hline $\begin{array}{l}\text { Nitrogen } \\
(\%)\end{array}$ & $\begin{array}{l}\text { IS } \\
14684\end{array}$ & 0.3 & 0.65 & 1.7 \\
\hline Sulphur (\%) & 0.1 & 0.65 & 0.01 \\
\hline $\begin{array}{l}\text { Phosphorous } \\
(\%)\end{array}$ & 1.1 & 0.63 & 0.002 \\
\hline Sodium (\%) & $\begin{array}{l}\text { Flame } \\
\text { Photo } \\
\text { meter }\end{array}$ & 0.03 & 0.34 & 0.02 \\
\hline $\begin{array}{l}\text { Potassium } \\
(\%)\end{array}$ & $\begin{array}{l}\text { Flame } \\
\text { Photo } \\
\text { meter }\end{array}$ & 0.04 & 0.36 & 0.01 \\
\hline
\end{tabular}

Table 6 First Day Readings

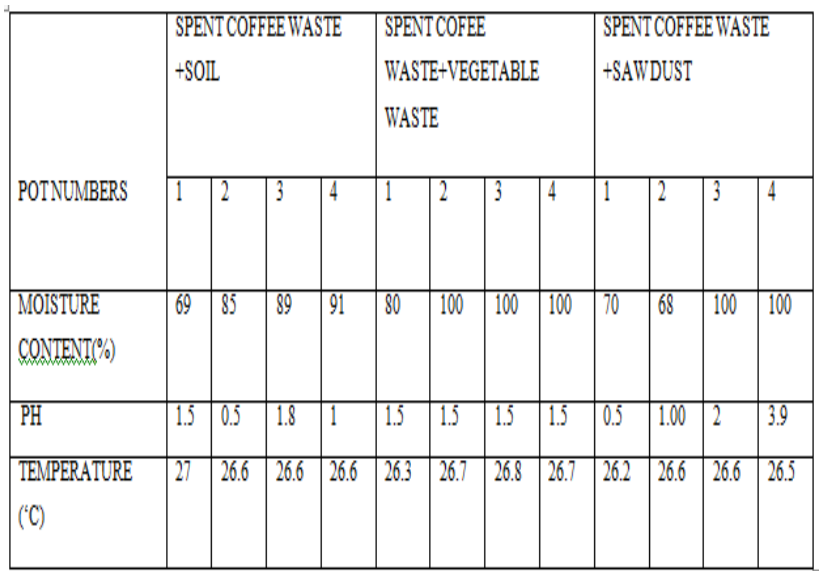

Table 7 Elemental Characteristics of the Compost

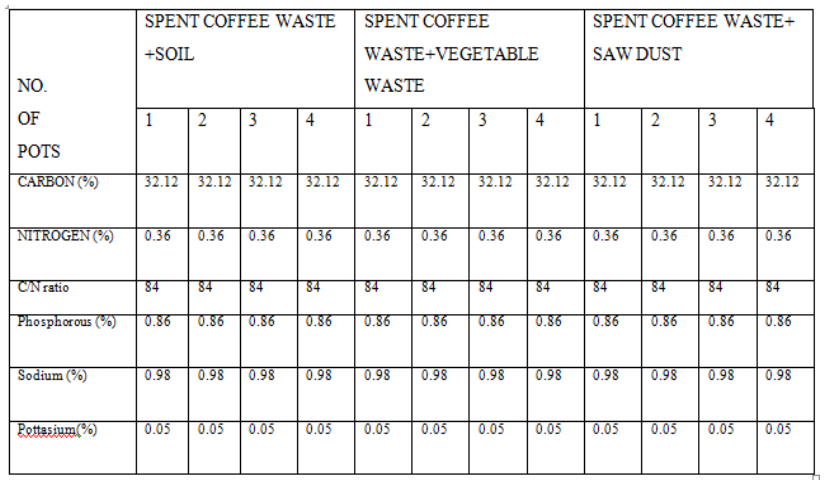

\section{CONCLUSION}

Espresso industry is also accountable for the age of a ton of solid wastes. For all intents and purposes all made and juvenile countries are endeavoring to acclimate to this reality by changing their methods with the objective that their developments can be reused. Dependent upon the sort of coffee waste (coffee cherry husks, coffee squash, coffee silverskin or spent grounds) there are various application philosophies of the coffee waste use. For example, this waste can be used as sorbent for the removal of generous metals and hues from liquid game plans, making of fuel pellets or briquettes, for arrangingmolecule exchange material, age of a spirit refreshment, substrate for edible mushrooms creation, wellspring of ordinary phenolic cell fortifications, production of reusable cups, substrate for biogas and alcohol age, biodiesel age or treating the dirt, and similarly as a biomaterial in the phamaceutical business. The eventual outcomes of the treating the dirt methodology are showed up in table 6 and 7 .

\section{REFERENCES}

1. Iyappan L., Dayakar P., Identification of landslide prone zone for coonoortalukusing spatial technology, International Journal of Applied Engineering Research,V-9,I-22,PP-5724-5732,Y-2014.

2. Kumar J., Sathish Kumar K., Dayakar P.,Effect of microsilica on high strength concrete, International Journal of Applied Engineering Research,V-9,I-22,PP-5427-5432,Y-2014.

3. Dayakar P., Vijay Ruthrapathi G., Prakesh J., Management of bio-medical waste, International Journal of
Applied
Engineering

Published By: 
Research,V-9,I-22,PP-5518-5526,Y-2014.

4. Swaminathan N., Dayakar P., Resource optimization in construction project, International Journal of Applied Engineering Research,V-9,I-22,PP-5546-5551,Y-2014.

5. Venkat Raman K., Dayakar P., Raju K.V.B.,An experimental study on effect of cone diameters in penetration test on sandy soil, International Journal of Civil Engineering and Technology,V-8,I-8,PP-1581-1588,Y-2017.

6. Saritha B., Chockalingam M.P.,Photodradation of malachite green DYE using TIO2/activated carbon composite,International Journal of Civil Engineering and Technology,V-8,I-8,PP-156-163,Y-2017

7. Shendge R.B., Chockalingam M.P., Saritha B., Ambica A.,Swat modelling for sediment yield: A case study of Ujjani reservoir in Maharashtra India,International Journal of Civil Engineering and Technology,V-9,I-1,PP-245-252,Y-2018

8. Chockalingam M.P., Balamurgan V.,Modernisation of an existing urban road-sector in Chennai, a case study report,International Journal of Civil Engineering and Technology,V-8,I-8,PP-1457-1467,Y-2017

9. Saritha B., Chockalingam M.P.,Adsorption study on removal of basic dye by modified coconut shell adsorbent, International Journal of Civil Engineering and Technology,V-8,I-8,PP-1370-1374,Y-2017

10. Saritha B., Chockalingam M.P.,Adsorptive removal of heavy metal chromium from aqueous medium using modified natural adsorbent,International Journal of Civil Engineering and Technology,V-8,I-8,PP-1382-1387,Y-2017

11. Chockalingam M.P., Palanivelraja S.,Retrospective analysis of a theoretical model used for forecasting future air quality near the north Chennai thermal power plant,International Journal of Civil Engineering and Technology,V-8,I-8,PP-1457-1467,Y-2017

12. Saritha B., Chockalingam M.P.,Photodegradation of methylene blue dye in aqueous medium by $\mathrm{Fe}-\mathrm{AC} / \mathrm{TiO} 2$ Composite,Nature Environment and Pollution Technology,V-17,I-4,PP-1259-1265,Y-2018

13. Shendge R.B., Chockalingam M.P., Kaviya B., Ambica A.,Estimates of potential evapotranspiration rates by three methods in upper Bhima Basin, In Maharashtra, India,International Journal of Civil Engineering and Technology,V-9,I-2,PP-475-480,Y-2018

14. Shendge R.B., Chockalingam M.P.,The soil and water assessment tool for Ujjani Reservoir,International Journal of Mechanical Engineering and Technology,V-9,I-2,PP-354-359,Y-2018

15. Shendge R.B., Chockalingam M.P.,A review on soil and water assessment tool,International Journal of Mechanical Engineering and Technology,V-9,I-2,PP-347-353,Y-2018

16. Sachithanandam P., Meikandaan T.P., Srividya T.,Steel framed multi storey residential building analysis and design,International Journal of Applied Engineering Research,V-9,I-22,PP-5527-5529,Y-2014

17. Meikandaan T.P., Ramachandra Murthy A.,Study of damaged RC beams repaired by bonding of CFRP laminates,International Journal of Civil Engineering and Technology,V-8,I-2,PP-470-486,Y-2017

18. Meikandaan T.P., Ramachandra Murthy A.,Retrofittng of reinforced concrete beams using GFRP overlays,International Journal of Civil Engineering and Technology,V-8,I-2,PP-423-439,Y-2017

19. Meikandaan T.P., Ramachandra Murthy A.,Flexural behaviour of RC beam wrapped with GFRP sheets,International Journal of Civil Engineering and Technology,V-8,I-2,PP-452-469,Y-2017

20. Meikandaan T.P., Murthy A.R.,Experimental study on strengthening of rc beams using glass Fiber,International Journal of Civil Engineering and Technology,V-9,I-11,PP-959-965,Y-2018

21. Meikandaan T.P., Hemapriya M.,Use of glass FRP sheets as external flexural reinforcement in RCC Beam,International Journal of Civil Engineering and Technology,V-8,I-8,PP-1485-1501,Y-2017

22. Saraswathy R., Saritha B.,Planning of integrated satellite township at Thirumazhisai,International Journal of Applied Engineering Research,V-9,I-22,PP-5558-5560,Y-2014

23. Saritha B., Ilayaraja K., Eqyaabal Z.,Geo textiles and geo synthetics for soil reinforcement,International Journal of Applied Engineering Research,V-9,I-22,PP-5533-5536,Y-2014

24. Ambica A., Saritha B., Changring G., Singh N B., Rajen M., Salman Md.,Analysis of groundwater quality in and around Tambaram taluk, Kancheepuram district,International Journal of Civil Engineering and Technology,V-8,I-8,PP-1362-1369,Y-2017

25. Arunya A., Sarayu K., Ramachandra Murthy A., Iyer N.R.,Enhancement of durability properties of bioconcrete incorporated with nano silica,International Journal of Civil Engineering and Technology,V-8,I-8,PP-1388-1394,Y-2017

26. Ilayaraja K., Krishnamurthy R.R., Jayaprakash M., Velmurugan P.M., Muthuraj S.,Characterization of the 26 December 2004 tsunami deposits in Andaman Islands (Bay of Bengal, India),Environmental Earth Sciences,V-66,I-8,PP-2459-2476,Y-2012

27. Ilayaraja K.,Morphometric parameters of micro watershed in Paravanar sub-basin, Cuddalore District,International Journal of Civil Engineering and Technology,V-8,I-8,PP-1444-1449,Y-2017
28. Ilayaraja K., Singh R.K., Rana N., Chauhan R., Sutradhar N.,Site suitability assessment for residential areas in south Chennai region using remote sensing and GIS techniques,International Journal of Civil Engineering and Technology,V-8,I-8,PP-1468-1475,Y-2017

29. Ilayaraja K., Reza W., Kumar V., Paul S., Chowdhary R.,Estimation of land surface temperature of Chennai metropolitan area using Landsat images,International Journal of Civil Engineering and Technology,V-8,I-8,PP-1450-1456,Y-2017

30. Chitra R.,Experimental study on beam using steel fiber and latex,International Journal of Civil Engineering and Technology,V-8,I-8,PP-1395-1403,Y-2017

31. Chitra R.,Analysis of traffic and management at Kovilambakkam intersection,International Journal of Civil Engineering and Technology,V-8,I-8,PP-1433-1443,Y-2017

32. Aswathy M.,Experimental study on light weight foamed concrete,International Journal of Civil Engineering and Technology,V-8,I-8,PP-1404-1412,Y-2017

33. Aswathy M.,Wastewater treatment using constructed wetland with water lettuce (Eichornia Crasipies),International Journal of Civil Engineering and Technology,V-8,I-8,PP-1413-1421,Y-2017

34. Kiruthiga K., Anandh K.S., Gunasekaran K, Assessment of influencing factors on improving effectiveness and productivity of construction engineers, 2015, International Journal of Applied Engineering Research, V $-10, \mathrm{I}-17, \mathrm{p}-13849-13854$

\section{AUTHORS PROFILE}

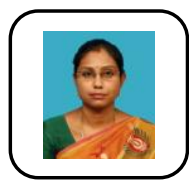

Saritha B, Associate Professor, Department of Civil Engineering, Bharath Institute of Higher Education and Research, Chennai, India

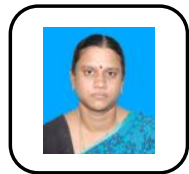

Maria Subashini L,Assistant professor, Department of Civil Engineering, Bharath Institute of Higher Education and Research, Chennai, India

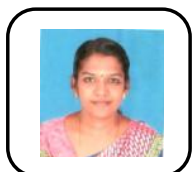

Aswathy.M Assistant professor Department of Civil Engineering, Bharath Institute of Higher Education and Research, Chennai, India 